Appl. Res. J. Humanit. Soc. Sci.

Vol 3(3), pp. 1-13, November, 2020

DOI: $10.47721 /$ ARJHSS202003018

Article number: SE-J-ARJHSS-2020.0303001

ISSN 26735614

https://skies.education/arihss

\title{
A Contextual Analysis of Three Major Tribes' Traditional Conflict Resolution Mechanisms in Pre-Literate Nigerian Society
}

\author{
Olowolafe, Oluwakemi Veronica ${ }^{1}$, Olawale Yinusa Olonade ${ }^{2 *}$, Christiana Olufunke Adetunde ${ }^{2}$ \\ ${ }^{1}$ School of Postgraduate Studies, Covenant University, Ota, Nigeria \\ ${ }^{2}$ Department of Sociology, Covenant University, Ota, Nigeria \\ *Corresponding e-mail: olawale.olonade@ covenantuniversity.edu.ng \\ Mobile number: 07032467376
}

\begin{abstract}
This paper contextually analyzed three major tribes' traditional conflict resolution mechanism in pre-literate Nigerian society. Conflict is very much part of human society and it is expected. Conflict resolution encompasses a range of processes gallantly aimed at alleviating or eliminating sources of conflict. Secondary sources of data with relevant literature were engaged and the Emile Durkheim theory of societal development was adopted as a theoretical framework. Findings show that in Yorubaland, conflict is seen as unavoidable, a positive development through which people understand each other better. While the main causes of conflict among the Igbos are basically land, chieftaincy tussle and matrimonial fallouts. Prior to kingship institution, the Igbo used non-centralized forms of government which have in attendance Elders and Council of Elders which serves as the highest and most important peacemaking and conflict resolution mechanism. Hausa/Fulani pre-colonial administration is highly centralized and hierarchical in nature. The Emir, in terms of adjudication, is both the political and religious head because he ensures that the provisions of Sharia are adequately followed to the core in treating cases of individual or group conflicts. The Emir court was the highest and the final. Having perused all the conflict resolution mechanisms of the three major tribes in Nigeria, the following recommendations were made; there is a need to encourage traditional conflict mechanisms as it is accessible and economic for disputants. There should be peace education for all and sundry. Alternative dispute resolution and unofficial strategies should be subscribed to in an attempt to ameliorate and manage human's conflicts (vigilante, militias, charms, prayers, communal solidarity, etc).
\end{abstract}

Keywords: Tribes, Traditional, Pre-illiterate, Conflict Resolution

\section{INTRODUCTION}

No society is free of conflict. It exists long before the colonization of Africa and it was the task of the traditional leaders to solve these conflicts Most of the African societies still prefer the use of traditional justice and reconciliation platform to resolve conflict. This is due to the agrarian, primitive and camaraderie nature of African society couple with low justice facility system. Even where present, there is favouritism 
and money bags judgement. Nigeria as a nation-state has encountered a myriad of complex problems involving different variables and stakeholders, as a result of which it has experienced an economic downturn, political upheavals, coups d'état, civil war, and a deluge of ethno-religious conflicts [1]. The traditional elders and chiefs on their respective parts have been mediating in violent conflicts where they give penalties which focus on compensation and restitution in order to restore status quo and maintained norms and normalcy. These traditional entities also serve as facilitators, reconciliatory, mediators and progenitor of peace, tranquil society and serene relationship.

People- male and female, young and old should live harmoniously in the community without fear and violent conduct. African societies celebrate and have a preference for traditional institutions because they depict African cultures and traditions of oneness and unity. Such institutions are accessible, allow flexibility in its proceedings and re-establishes social harmony [2]. Sad to state that their roles have been relegated to the background, remained null, of no effect, weak and unrecognizably abandoned. Conflict managers and foreign institutions have gained momentum [3]. Traditional conflict resolution mechanisms cannot be easily washed off even with the introduction of courts, legal personnel and facilities. They are still being employed in regulating conflict and providing justice in Africa and most especially in Nigeria. Hence, their role can never be overlooked. It is against this backdrop that the study examines in a contextual analysis the three major tribes' traditional conflict resolution mechanism in pre-literate Nigerian society.

\section{CONCEPTUAL REVIEW}

\section{Conflict}

Conflict is very much part of human society. Every society can be enmeshed in crises because it characterized the human race, interactions whether at the individual or group level. Indeed, considering the social organization and attitude of the people, it should be expected that they would experience conflicts at interpersonal and inter-group levels. After all, it is often said that social relations engender conflicts. Human beings share individual differences, so when they live together- their social relations due to perception of lies, attitudes and an overview may at one time or the other degenerate into conflicts. This is true for various tribes in Nigeria, most especially the three main sub and distinct groups (Wilson and Hanna). Their perception of the world view is entirely parallel. Hence, Conflict is the struggle involving ideas, values and limited resources. It is the class struggle over values and claims to scarce resources, status and power in which the opposing force is meant to dement, neutralize, injure and destroy. Chaplin (1979) defines conflict as "the simultaneous occurrence of two or more mutually antagonistic impulses or motives"4.

Conflict can be defined as the manifestation of a hostile attitude in the face of conflicting interests between individuals, groups or states. Albert (2002) observes that the human perception of reality is very 
important in the understanding of a conflict situation ${ }^{[5]}$. Folger and Daudu (1997:69) have identified five key features of conflict interaction that ${ }^{[6]}$ :

$\checkmark \quad$ Conflict interaction is characterized by moves and counter-moves which are themselves determined by the power wielded by the parties involved;

$\checkmark \quad$ The pattern of behaviour tends to be sustained;

$\checkmark \quad$ Steps taken in the course of such interaction are products of the larger environment in which they take place;

$\checkmark \quad$ There is a general understanding of the direction of such interaction; and

$\checkmark \quad$ Such interaction impacts the relationship between the parties involved.

It is also important to state that conflicts occur at different levels. These levels are:

$\begin{array}{ll}\boldsymbol{v} & \text { Intra-personal } \\ \boldsymbol{\checkmark} & \text { Inter-personal } \\ \boldsymbol{\checkmark} & \text { Intra-group/Community } \\ \boldsymbol{\checkmark} & \text { Inter-Group/community }\end{array}$

\section{Conflict resolution}

The concept of conflict resolution encompasses a range of processes gallantly aimed at alleviating or eliminating sources of conflict. It is sometimes used with the word dispute resolution. It is a veritable vehicle to sustainable development and peaceful society. Conflict resolution depicts the modus operandi of reconciling scarce resources alongside qualified persons and positions in an atmosphere devoid of sentiments and injustices. Conflict resolution upheld efforts, strategies and approaches towards crisis prevention and management. It is however highly and tilting towards traditional and customary in nature that the formal legal style. In a plural society, its usage may be complex and cumbersome principally because of the determining factors of racial and tribal effects of culture and language symbolism.

The major tribes in Nigeria have several approaches that are used indigenously as a way of insulating their community from hostilities and recognizing their worth in their host community. Such approaches are otherwise referred to as culture-based. Conflict resolution provides an opportunity to interact with the parties concerned, with the hope of at least reducing the scope, intensity and effects of conflicts. During formal and informal meetings, conflict resolution exercises permit a reassessment of views and claims as a basis for finding options to crisis and to divergent points of view. Those who organize conflict resolution exercises or meetings usually constitute the third party in a triangular arrangement and consist of traditional rulers (King, Chiefs, etc). 


\section{Traditional institutions in the pre-literate Nigerian society}

Tradition refers to age-long, old, customary and established historic ways of doing something while institution means a system or organization that has existed for a long time among a particular group of people. Tradition refers to custom or belief which is a long-established action or pattern of behaviour in a community or among a group of people, often one that has been handed down from generations. It presupposes a body of customs that is, a body of long-established practices and beliefs viewed as a set of values by a culture. They are those social, economic or political organizations/bodies which derive their power, legitimacy, influence and authority from the traditions of a particular people. In the pre-colonial Africa, the set of people who control, direct and superintend over traditional institutions are called traditional rulers and their subordinates like provincial chiefs, princes, ward heads, etc. Indeed, the power, authority and legitimacy of traditional rulers were derived from traditions. Before the coming of the Europeans, the traditional rulers held sway not only as the recognized political rulers of the states and kingdoms in Nigeria but also as the custodians of the people's history, culture, religions and economy. The traditional institutions in Nigeria have gone through thick and thin in the country's political history from the pre-colonial, through the colonial and to the post-colonial eras. In the words of Biodun Adediran (n.d): "From the pre-colonial era, the traditional institutions have been strengthened and weakened, elevated and humiliated, empowered and disempowered by emergent political/ruling class".

This is why the African monarchs were and are still referred to as traditional rulers. Traditional rulers refer to the set of rulers of the various Nigerian peoples and communities before these people were brought together by the British colonial rulers in the establishment of Nigeria. For instance, in modern Nigeria, the categories of traditional rulers include the Mai/Shehu of Borno, the Habe and Emirs rulers in Hausaland, the Oba in Yorubaland, the Attah in Igalaland, the Etsu in Nupeland, the Obi and Eze in igbo land, etc ${ }^{[7]}$; ${ }^{[8]}$. These traditional rulers occupied and still occupy important positions among the peoples of pre-colonial and post-colonial Nigeria. Their positions were/are sanctioned by the traditions, history and culture of their respective peoples who hold them in high esteem and reverence.

Nigeria has traditionally had a large number of traditional authorities and rulers who have played an important role in community coherence and traditional justice systems. During the colonial era, the positions of existing authorities were recognised, and new chiefs were created to harmonise the system. Although this system has persisted until the present day, the rise of alternative poles of power, in particular, the local and state governments, has tended to undermine the powers of such individuals or councils. It has been observed in parts of Nigeria because traditional rulers' long establishment and the respect in which they are held makes them more effective in conflict resolution than 'official' mechanisms. They are also able to take pre-emptive action through their familiarity with the different sections of the community, where 
the government has been observed to be reactive. Some traditional rulers work extremely hard with little official recognition of their efforts.

\section{Conflict resolution in pre-colonial Yoruba land}

The traditional institutions in the pre-colonial Yorubaland had all elements of modern governmental systems and they perfectly suited the social, political and economic situations of the era with the overall goal of the welfare of the generality of the people. The advent of colonial rule and the imposition of Western styles of government not only reduced the powers and relevance of the traditional rulers but also made them subservient to their subjects, the educated elite. Since independence in 1960, the political statuses of traditional rulers have gone from bad to worse with far-reaching consequences for governance and administration in the country.

The Oba in Yorubaland is at the topmost hierarchy of the holders of traditional power and authority. An Oba in Yoruba traditional system was and still ordained by the community's spiritual/natural authorities, acceptable to and by the community as a role model and unquestionable leader- "kabiesi', An Oba is not only a mere head of a kingdom but he is "Awokoise", - role model; " Oba ba le ile, oba le oko" - 'father of all'; "IgbakejiOrisa", 'second only to the gods'. He is generally seen, recognized and acknowledged as the custodian of the people's history and culture. A Yoruba Oba personifies the kingdom and represents the reincarnation of the past ancestors of the community. The words of an Oba were orders and their actions were divine and sacred. Until the modern period, they were hardly seen in public except during important traditional festivals and religious celebrations. The Oba was/is assisted by a chain of traditional chiefs and loyalists who also form important parts of the traditional institution of government in Yorubaland ${ }^{[9]}$.

In Yorubaland, conflict is seen as unavoidable, a positive development through which people understand each other better. A popular Yoruba adage says: “Gbogbo nkan ko ni ija nbaje', meaning 'It is not all things that conflict spoils' (it can also be constructive). According to the Yoruba belief system, kinsmen that smile at each other on a daily basis without having any dispute at any time are only deceiving one another. It is believed that deep down in the hearts of such people conflict-related thoughts are harboured. Such grievances are better managed if the concerned parties come out to express them frankly and get the issues resolved. What is being implied here is that disputes should be amicably resolved, as they arise. Another popular Yoruba epithet says: “Ahon ati eyin nja, Ka ja ka pari re niyi omoluabi”, (The tongue and teeth often come in conflict, to quarrel and get reconciled is a mark of responsibility). A corollary to this is: "Ko si awaiye maja, Be si ni kosi a ja mare"' (No sojourner on earth is immune against dispute No disputants remain enemies forever)

Olaoba, (2005) explicitly puts it that Yoruba culture encourages reconciliation; however, going to court is often interpreted as a sign that the disputants do not favour reconciliation ${ }^{[10]}$. Those who choose to 
take their neighbours to the police station or the court are therefore often seen as wicked people, whom peace-loving people should avoid. Thus another popular Yoruba adage says: "A ki ti kotu bo sore" (We do not come back from the (formal) court and remain friends). Worthy of note is that when conflict happens, after a long discussion with the disputants and among themselves, the Elders announce their decision to the disputants. If the disputants accept the decision it will usually be reduced to writing. If one or more of the disputants refuse to accept the decision, there is no direct mechanism to enforce compliance. However, traditional sanctions will be imposed on the disputants. The social and cultural sanctions available include prohibiting attendance at cultural and social festivals and prohibiting the community from collaborating with the disobedient disputant, unwillingness to support them in time of wedding, funeral ceremonies and other labour sharing activities. In fact, Yoruba traditional institutions use different procedures such as oathtaking, swearing, blessing and cursing, which are of a transcendental nature. On this ground, hardly can one can get away with committing a crime and denying it.

\section{Conflict resolution in pre-literate traditional Igboland}

Igbo pre-colonial society is patriarchal in nature. Hence, the conflict resolution mechanism was and still an integral part of such a society. The absence of a centralized system of government among the people in the pre-colonial period did not mean that the people were in a state of anarchy. The Igbo society of old had laid down rules and regulations which guided the ways and manner at which conflicting situations are tackled and resolved for peace and tranquillity to reign. Oral history and even literature have it that the Igbo people had no chiefs but only paraded Alter chiefs but today, the institution of kingship is well pronounced and established with Igwes and Ezes providing leadership in collaboration with kindred chiefs. Prior kingship institution, the Igbo used non-centralized forms of government which have in attendance Elders and Council of Elders which serves as the highest and most important peacemaking and conflict resolution mechanism

The main causes of conflict among the Igbos are basically land, chieftaincy tussle and matrimonial fallouts ${ }^{[11]}$. The Igbo did not fight total wars or pitched battles in the pre-colonial period and did not celebrate war like most other African countries. Before colonialism, the Igbo did not just jump into social control or wait for conflict to start before control; they rather had institutions for controlling the suppression of weaker people from the stronger. According to Afigbo (1981), these following institutions carried out the task of peace education, peacebuilding, confidence building, peacemaking and peace enforcement as well as conflict monitoring, prevention, management and resolution ${ }^{[12]}$. According to ${ }^{[13]}{ }^{[14]}{ }^{[15]}{ }^{[16]}$, these institutions includes; Ezi (Family); Okpara (elders) man holding ancestral spear, (alo), and ofo); Umunna (clan); Umuada or Umuokpu (females born in a clan); Amala (Council of elders); Nzuko Obodo (village/town assembly); Oha-na-Eze (meeting of the king and the people); Ndi-isi Obodo (village heads); 
Ndimmanwu (masquerade group); Otu-Ogbo (age grades); Otu-ndi nta (hunters association); Ndi chili echichi (titled men, eg Ozo title-holders); Agbara (oracles/deities). These institutions handled conflicts at different levels in Igbo society. However, families/homes serve as the basic unit for teaching and preventing conflicts. The Okpara system did much of the conflict prevention and in as much that the Okpara could not handle is moved to the Umunna, or Umuada, and if necessary to the Amala. External agents were also used by the Igbo in managing conflicts. These were mainly elders from neighbouring villages or towns; and supernatural forces such as deities/oracles from far and near which were noted for their impartiality, and effectiveness in delivering just judgement and instant punishment, e.g. "Ibinukpabi" (Long juju of Arochukwu), Igwekala of Umunnoha in Owerri, Amadioha of Ozuzu, Ekwensu of Anaku, Urashi of Okija, Ogwugwu Akpu, and others [11] [13].

\section{Conflict resolution mechanism in pre-literate Hausa land}

Aside human interaction which could fuel skirmishes and crises, the genesis or part of crises in the Hausa/Fulani pre-colonial system is traceable and credited to the Holy Jihad fought by Uthman Danfodio in 1804 which is predominant in the Northern part of Nigeria covering areas like Kaduna, Sokoto, Kano, Zaria, etc. The system of government adopted is monarchical in nature popularly regarded as a highly centralized method of administration. Literature has espoused the prevalence of conflicts in northern Nigeria to a myriad of factors including economic factors (including resource allocation inequity) and indigene-settler issues, political factors and unbridled power tussle; While some of these studies have also identify religion and its politicization; ethnicity factors and colonialism's amalgamating of various ethnic groups as leading to Nigeria's high ethnocentric politics as well as Islamic fundamentalism ${ }^{\text {[1] [15] [16]. }}$.

Hausa/Fulani pre-colonial administration is highly centralized and hierarchical in nature. Hausa/Fulani emirates are headed by the emirs, in those days with two headquarters Sokoto and Gwandu in which Islamic rule serves as the guiding principle of the administration. To set the records straight, Emir is an absolute ruler because there is no principle of checks and balances. However, the main judicial institutions in the pre-colonial Hausa/Fulani include the Emir (the paramount ruler), the Emir's ministers and aides, District Head (Hakimi), the village heads and the Alkali court. Oyediji (2014) opined that Emir is the head of an emirate, vested with legislative, executive and judicial power ${ }^{[16]}$. He is an absolute ruler. That is, the Emir is supreme in decision making and whatsoever he ordered must be carried out, though with the tenet of Islamic laws called Sharia. The Emir, in terms of adjudication, is both the political and religious head because he ensures that the provisions of Sharia are adequately followed to the core in treating cases of individual or group conflicts. The Emir court was the highest and the final. The Emir had an advisory council who helped in the day to day administration including dispute settlement on cattle, land 
and matrimonies etc. they are referred to as Emir's minister. All disputants are submissive and subservient to the Emirs rules.

The Waziri is seen as the head and he championed the greater cause for smooth administration. He is in charge and carries out Emir's instruction on his behalf. Galadima, as a minister, oversees the affairs of the emirates (Emir's capital territory). Madawaki can be regarded as the commander of the Calvary (i.e. Commander of the Army). The Chief police officer is the Dogari whose responsibility is the security of lives and properties. The Alkali court takes charge of judicial administration of the emirate under Islamic Tenet-Sharia which is being administered by appointed Islamic judges- the Chief Alkali or Grand Khadi, according to Emmanuel (2016), Hausa-Fulani are conservative, reserved, calculating and feudalistic, possessing of uncanny political engineering wizardry, with a single-minded pursuit of hegemonic power and political leadership of post-independence Nigeria ${ }^{[17]}$. Their religious intolerance, love for power and their insistence on having it their own way could, arguably, explain conflicts is the order of the day and the strong laid down hierarchical means of settling disputes by the emirs.

\section{Conflict Resolution strategy among the three main tribes in Nigeria: The Nexus}

Over the years, African society prevents conflicts or conflicting situations by their own means and through their own strategies. They built a wealth of experiences, mechanisms and institutions to peacefully ameliorate and mediate and succinctly work through the reconciliation process with disputants. All of these contextually assessed tribes in Nigeria shared lots in common. This ranges from family or household head, the council of elders or chiefs, religious leaders, age-grades, local court, kingship mechanisms, compensatory as well as punishment processes and healing ceremonies. Expressly, family constituted the lowest court in the traditional Nigeria cum African system wherein the king and his council formed the highest court of Appeal. They symbolize the third-party intervention in conflict resolution mechanisms.

According to Nwolise (2005), he submits that in traditional thoughts, letters, writing, beliefs and philosophy, the third party is expected to be neutral and possess the capability to diffuse tension, listen to all sides, restore peace and put social mechanisms in place for conflict resolution ${ }^{[18]}$. He narrated the fact that African traditional societies hold secrets of peacemaking and peacebuilding which are woven around core traditional culture, customs and belief systems before the colonial masters disrupted. Even with the advent of modernization, these ethos and traditional institutions are still holding sway and gaining ground. They are still weaving the society together with core societal principles of peace, solidarity, harmony and camaraderie. In as much as the modern adjudication system has been practised, there is no gainsaying that traditional conflict resolution in core Nigeria societies had been in existence for centuries and are still causing waves till date in their own class and status. 
Culture experts posit that each tribe, race, identity and groups in the world have their own ways, manner and approaches of settling disputes, controlling societal relational behaviours and conflict resolution. In developed societies, like Europe, Asia, they rely on policing systems to fight crimes and resolve conflicts while several African societies relied on oath-taking, divination and blood covenant to wage war against stubborn disputants, social miscreants and criminals. These traditional methods were geared towards restoring peace and not vilification or punishment of offenders. They are there to checkmates and serve as deterrence for people in pre-colonial times. Emphasis was laid on reconciliation and restoration of social harmony among disputants. The Europeans thrive on commissions of inquiries, constitutions and the court system of lawyers and judges, Africa uses council of elders, king's courts, people's assemblies etc for dispute management and justice dispensation.

\section{THEORETICAL FRAMEWORK}

\section{Emile Durkheim theory of development}

Durkheim introduced the terms "mechanical" and "organic solidarity" as part of his theory of the development of societies in The Division of Labour in Society (1893). Mechanical Solidarity and Organic Solidarity are the concepts of solidarity used in the context of differentiating between mechanical and organic societies. The types of social solidarity correlate with types of society. The above distinction reveals Durkheim's thinking about how modern societies differ from pre-industrial ones, and consequently, how solidarity changes as a society becomes more complex. According to Durkheim, Mechanical solidarity, in general, operates in "traditional" and small-scale societies. In simpler societies (e.g., tribal), solidarity is usually based on kinship ties of familial networks. A society that exhibits mechanical solidarity is characterized by the depth of its cohesion and integration which comes from the homogeneity of individuals-people feel connected and attached to themselves among other things, the lifestyle.

Durkheim submits that individuals are bound together by the aforementioned two types of social solidarity. The name 'mechanical' was used to describe the pre-industrial societies while 'organic' denoted the industrial societies. In mechanical solidarity, individuals are strongly attracted to each other which is the general condition for social cohesion and integration. Collective life and long-established social bonds predominate in societies identified as mechanical. According to Durkheim, the following features stood them out: A small, isolated homogenous population; Little or no specialization; Division of labour based on cooperation; System where social links are based on custom, obligation and emotion; Shared values and beliefs; A system of social institutions in which religion is dominant; Produced a system of social cohesion; Legal system is based on repressive sanctions, which serves to reaffirm traditional values; Little individual freedom; As a result of the dominance of a few shared values, society can mobilize en masse; System in which individualism is undeveloped. 


\section{Application of Emile Durkheim theory of development to this study}

In African society, the function of elders has arguably been undermined (if not eradicated) by the onslaught of colonialism, politics, widespread violence and modernity, yet they are enduring institutions. Relational interdependence is one of the key features of traditional forms of conflict resolution, often described as a 'warp and weft' approach. Elders are seen as important for their symbolic connection to the past, and for their knowledge of traditional ways, teachings, stories and ceremonies. The Elders are called upon to help communities with decisions regarding everything from health issues to community development, to governmental negotiations regarding land use and self-government ${ }^{[19]}$. They are repositories of cultural and philosophical knowledge and transmitters of such information.

These traditional teachings illuminate the interconnectedness of all things, including the connections between individuals who are in conflict with each other. Furthermore, Native elders also establish connections between future generations and the outcomes of current disputes. Participants are always reminded to think of the effects of their actions upon upcoming generations. Participants are admonished to consider the effect of their decisions upon 'the next seven generations'. From the foregoing, traditional approaches are obviously and basically dependent on "the existence of a community of relationships and values to which they can refer and that provide the context for their operations. Relationships are a precondition for the effective operation of the modes of conflict management. or - to be more precise relationships that are rooted in a common view of the world and a shared acknowledgement of customary institutions. There were some significant principles in the traditional culture that regulated the nature of human relations. Interconnection of all living life was a very important part of the traditional Yoruba worldview. According to that belief, inappropriate behaviour hurts not only a troublemaker but the entire family and community. The consensus was an important principle of the traditional Yoruba way of conflict resolution. It denotes working together, characterised by open discussion, geared towards reaching a mutual agreement on how to best repair the harm and restore balance and harmony to the disrupted relations.

Durkheim's mechanical solidarity implies that solidarity comes from similarities or likeness, and it's at the maximum when the collective conscience completely envelops our total consciousness. This does permeate the early traditional societies and such societies are relatively homogenous. Durkheim claims that in such societies, "The solidarity that derives from similarities is at its maximum when the collective consciousness completely envelops their total consciousness, coinciding at every point”. It was made up of rules which are practised by all. A group is not only a moral authority which dominates the life of its members; it is also a source of life sui generis."

It is not possible for a social function to exist without moral discipline thus, society is seen as a complex of ideas and sentiments, of ways of seeing and of feeling, a certain intellectual and moral framework distinctive of the entire group ${ }^{[20]}$. The totality of beliefs and sentiments common to average 
citizens of the same society forms a determinate system which has its own life; one may call it the collective or common conscience. Otherwise, nothing remains but individual appetites, and since they are by nature boundless and Insatiable, if there is nothing to control them, they will not be able to control themselves.

\section{CONCLUSIONS AND RECOMMENDATIONS}

\section{Summary and conclusions}

Conflict is indeed an inevitable aspect of human existence. It is a kind of social unrest or relationships either positive or negative and is in the magnitude of rage, rift, misunderstanding, family and market brawls, skirmishes and wars and widespread in traditional African societies. Each tribe, race, or identity group has her own ways of doing things especially as they concern conflict resolution. Various communities in precolonial Nigeria had varied conventions aimed at mitigating inter-human and intra and inter-communal conflicts. These conventions were not without being backed by taboo which must be observed for peaceful regulation of human activities such as cohabitation, the relationship between husband and wife, father and children, one community and the other among others.

Efficient and effective management of conflicts is fundamental to the development of any society, but the prevailing situations in Nigeria constitute a reversal of this reality. The Nigerian success story of amalgamation of diverse groups in 1914 has radically shifted from a platform for peaceful coexistence to an arena of violence and gradual disintegration. Nigerian government's capacities for managing conflicts are weak and appear valid because the government has not fully considered the utility of every available strategy for conflict management. When conflicts erupt, the inability of the Nigerian mobile police to manage them usually prompts the Nigerian government to deploy the Nigerian military to the scene of violence where the military are usually mandated to 'shoot on sight.' This situation sometimes leads to serious human rights violations and escalation of violence. The state's imposition of curfew and use of propaganda to douse public tension are part of the Nigerian government's regular strategies for conflict management in Nigeria which has failed woefully.

\section{Recommendations}

The uncritical adoption of western approaches to conflict resolution mechanisms has an adverse effect on the stability, camaraderie and unity of the African societies. Hence the following recommendations are made.

i. There is a need to encourage traditional conflict mechanisms as it is accessible and economic for disputants as disputes are inevitable.

ii. There should be peace education for all and sundry. Education and training about peace and unity should be the order of the day. There should be all activities which improve attitudes, knowledge and capabilities for conflict management; peaceful coexistence and practical multiculturalism principles. 
iii. Alternative dispute resolution and unofficial strategies should be subscribed to in an attempt to ameliorate and manage human's conflicts (vigilante, militias, charms, prayers, communal solidarity, etc)

iv. Working in partnership with the government, especially at a local level, to promote a peaceful and tranquil society.

v. There should be core respect and recognition for aged or senior citizens to help in sustaining peace and security by tackling the sign of conflicts at the beginning.

\section{REFERENCES}

[1] Onyekpeze (2002), F. A. "Life and People of Abavo Kingdom”, Krisbec Publications, Agbor, 2002, page 238-239.

[2] Wilson and Hanna M.S. (1990) Groups in Conflict: Leadership and Participation in Small Groups. McGraw College, New York

[3] Wallestein, I. (2002). Understanding Conflict Resolution. Sage, London

[4] Chaplin J. P. (1979). Dictionary of Psychology. Dell Publishing, New York.

[5] Albert I. O. (2001). Introduction to Third-Party Intervention in Community Conflict. Ibadan: John Archers Publishers Ltd., Ibadan

[6] Folger, A. and Dauda, G. K. (2009). Indigenous Conflict Resolution Methods Amongst the Fulbe of Adamawa State. Centre for Nigerian Languages Bayero University, Kano

[7] Albert O. I. (2001) New Directions in the Management of Community Conflicts in Nigeria: Insights from the Activities of AAPW. Community Conflicts in Nigeria, Management, Resolution.

[8] Oguntomisin, G. O. (2004). The processes of peacekeeping and Peace -Making in Pre-Colonial Nigeria. Ibadan: John Archers, pg 10

[9] Oguntola-Laguda, D. (2006). The Role of Traditional Rulers and Religious Leaders in Conflict Management in Nigeria. the Practice of Religion in Nigeria, Decency Printers, Ilorin. IAARR 2014: www.afrrevjo.net 154 Indexed African Journals Online: www.ajol.info

[10] Olaoba, O. B. (2005). Ancestral Focus and the process of conflict resolution in Traditional African societies\|: Albert, A. O. (ed.) In Perspectives on Peace and Conflict in Africa in Essays in Honour of General (Dr) Abdulsalam A, Abubakar, Ibadan: John Archers Ltd.

[11] Alloysius, D. (2009). Igba Ndu In Igboland Igba Ndu, Igbo Land., www.ngrguardiannews.com/Arts/Article01/Indexn2_Html, Norwegian Refugee Council, (NRC) 2005

[12] Afigbo A. E. (1981). Ropes on Sand: Studies in Igbo History and Culture, London: Oxford University Press. 
Olowolafe, O. V, Olonade, O. Y and Adetunde, C. O. (2020): A Contextual Analysis of Three Major Tribes' Traditional Conflict Resolution Mechanisms in Pre-Literate Nigerian Society.

[13] Nwabara S.N. (1977). Igbo Land: A Century of Contact with Britain 1860-1960, London: Hodder and Stoughton Association for Conflict Resolution 2018 What is Conflict Resolution? https://www.gdrc.org/u- gov/ugov-mediate.html

[14] Chubb L.T. 1961 Ibo Land Tenure, 2nd Edition, Ibadan: O.U.P.

[15] Economic Commission for Africa, Relevance of African Traditional Institutions of Governance, Addis Ababa, $\quad 2007 \quad$ http://erepository.uonbi.ac.ke:8080/handle/123456789/4088 http://www.un.org/en/peacekeeping/missions/past/unosom1backgr2.html www.wfp.org

[16] W.H.O. (2002). Proposed working definition of an older person in Africa for the MDS Project.www.un.org/en/documents/charter/preamble.shtml

[17] Emmanuel, M. (2016). Federalism in Nigeria Between Divisions in Conflict and Stability in Diversity Geneva: Globethics.net, 2016 ISBN 978-2-88931-106-4 (online version) Globethics.net

[18] Nwosile O. B. (2005). Traditional Models of Bargaining and Conflict Resolution in Africa: Perspective on Peace and Conflict in Africa. Ibadan: John Archers Ltd.,

[19] Zistel B. S., (2008). Conflict Transformation and Social Change in Uganda, Remembering After Violence, New York, Palgrave Macmillan, 2008

[20] Zartman I. W., et al, Getting In 'Mediators Entry into the Settlement of African Conflicts', Washington D.C, United States Institute of Peace Press, 2006 